\title{
Association of high-sensitivity C-reactive protein and odds of breast cancer by molecular subtype: analysis of the MEND study
}

Anjali Gupta ${ }^{1,2}$, Taofik Oyekunle ${ }^{2}$, Omolola Salako ${ }^{3}$, Adetola Daramola ${ }^{3}$, Olusegun Alatise ${ }^{4}$, Gabriel Ogun ${ }^{5}$, Adewale Adeniyi ${ }^{6}$, April Deveaux ${ }^{2}$, Veeral Saraiya7, Allison Hall $^{8}$, Omobolaji Ayandipo5, Thomas Olajide ${ }^{3}$, Olalekan Olasehinde ${ }^{4}$, Olukayode Arowolo4, Adewale Adisa ${ }^{4}$, Oludolapo Afuwape ${ }^{5}$, Aralola Olusanya ${ }^{5}$, Aderemi Adegoke $^{9}$, Trygve 0. Tollefsbol ${ }^{10}$, Donna Arnett ${ }^{11}$, Michael J. Muehlbauer ${ }^{12}$, Christopher B. Newgard ${ }^{12}$, H3 Africa Kidney Research Network ${ }^{13}$ and Tomi Akinyemiju ${ }^{2,14,15}$

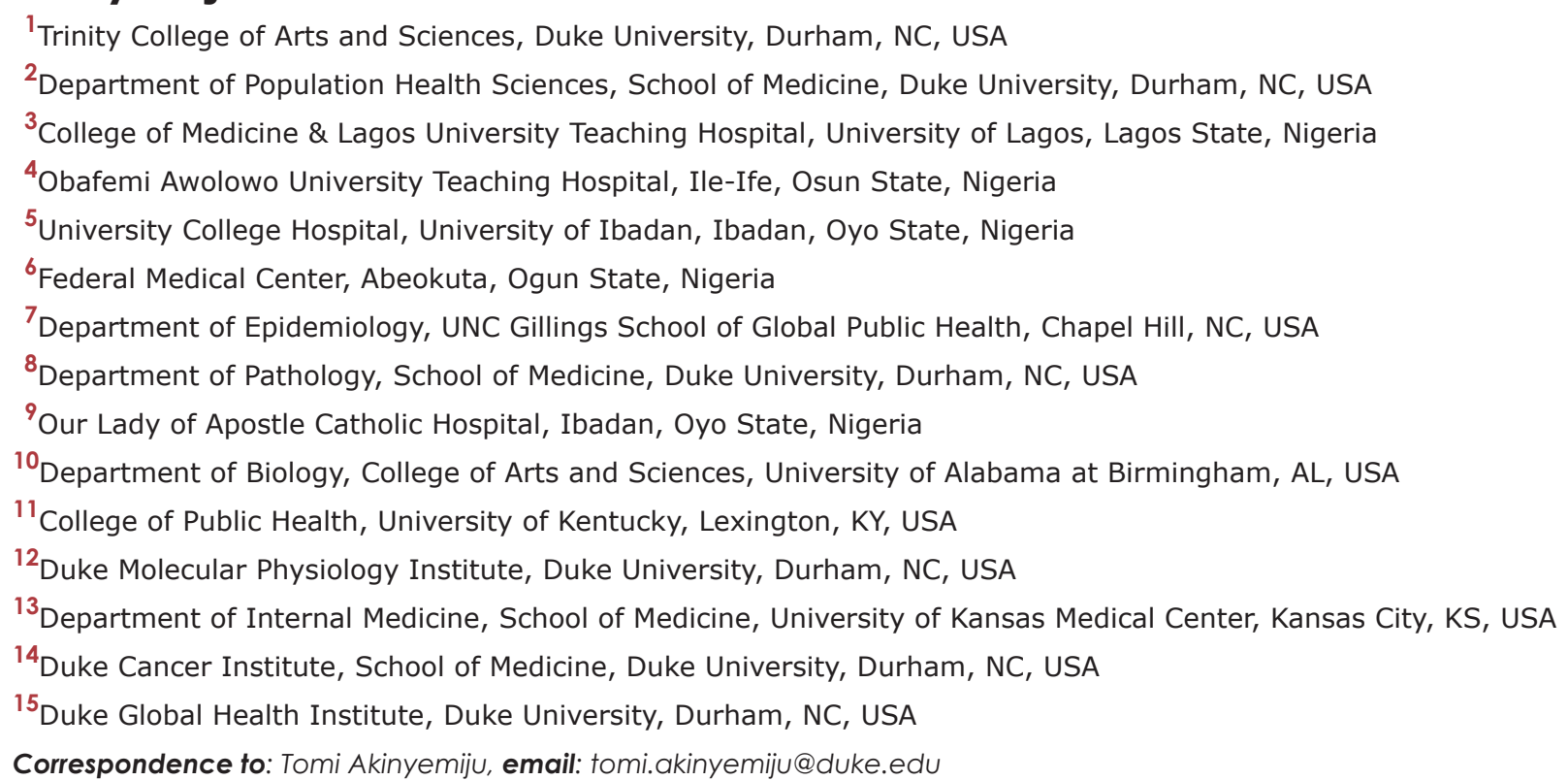

Correspondence to: Tomi Akinyemiju, email: tomi.akinyemiju@duke.edu

Keywords: C-reactive protein; breast cancer; Nigeria; molecular subtype; menopausal status

Received: May 14, $2021 \quad$ Accepted: June 02, $2021 \quad$ Published: June 22, 2021

Copyright: $\odot 2021$ Gupta et al. This is an open access article distributed under the terms of the Creative Commons Attribution License (CC BY 3.0), which permits unrestricted use, distribution, and reproduction in any medium, provided the original author and source are credited.

ABSTRACT

Breast cancer (BC) in Nigeria is characterized by disproportionately aggressive molecular subtypes. C-reactive protein (CRP) is associated with risk and aggressiveness for several types of cancer. We examined the association of high-sensitivity CRP (hsCRP) with odds of BC by molecular subtype among Nigerian women. Among 296 newly diagnosed BC cases and 259 healthy controls, multivariable logistic regression models were used to estimate adjusted odds ratios (aOR) and $95 \%$ confidence intervals (CI) for the association between hsCRP and odds of BC overall and by molecular subtype (luminal A, luminal B, HER2-enriched and triple-negative or TNBC). High hsCRP ( $>3 \mathrm{mg} / \mathrm{L}$ ) was observed in $57 \%$ of cases and $31 \%$ of controls and was associated with 4 times the odds of BC (aOR: 4.43; 95\% CI: 2.56, 7.66) after adjusting for socio-demographic, reproductive, and clinical variables. This association persisted regardless of menopausal status and body mass index (BMI) category. High hsCRP was associated with increased odds of TNBC (aOR: 3.32; 95\% CI: 1.07, 10.35), luminal A BC (aOR: 4.03; 95\% CI: 1.29, 12.64), and HER2-enriched BC (aOR: $6.27 ; 95 \%$ CI: $1.69,23.25$ ). Future studies are necessary in this population to further evaluate a potential role for CRP as a predictive biomarker for BC. 


\section{INTRODUCTION}

In 2018, there were over 2 million cases and 0.6 million deaths from breast cancer (BC), making it the most common cancer globally among women [1]. The past few decades have seen rising $\mathrm{BC}$ incidence rates on the African continent [2], with the highest age-standardized mortality rate within the continent in Nigeria [3]. BC in Nigeria is characterized by disproportionately aggressive molecular subtypes, with exceptionally high rates of triple-negative (TN) $\mathrm{BC}$ [4], similar to $\mathrm{BC}$ in other countries in West Africa [5] and among African American women in the United States [6]. TNBCs are estrogen $(\mathrm{ER})$, progesterone (PR), and human epidermal growth factor-2 (HER2) receptor negative, and less responsive to treatment compared to less aggressive subtypes, leading to poor clinical outcomes [7]. The complex associations of genetic, environmental and lifestyle factors contributing to aggressive $\mathrm{BC}$ subtypes are areas of active research [8], and recent studies suggest that chronic inflammation, involving both innate and adaptive immunity, may contribute to tumor heterogeneity and aggressiveness [9]. Despite the well-documented patterns of late stage, distant metastasis and TN subtype tumors among African women, no study to our knowledge has directly examined biomarkers of chronic inflammation in relation to odds of $\mathrm{BC}$ and molecular subtypes in Nigerian women.

$\mathrm{C}$-reactive protein (CRP) is an easily measurable biomarker that reflects systemic inflammation, infection, or tissue damage in the body, and may be elevated in both acute and chronic conditions [10,11]. Circulating levels of CRP have been shown to be elevated in various types of cancers from case-control or cross-sectional studies [12]. In addition, circulating levels of CRP have also been associated with tumor prognosis in patients with several types of solid cancers [13]. Many past studies in the United States, Europe, and Asia have evaluated the association between CRP levels in the blood and $\mathrm{BC}$ risk. One systematic review reported a significant positive association between elevated levels of CRP and risk of $\mathrm{BC}$, noting that geographic region might be a possible source of heterogeneity in results, with stronger associations observed among participants from Asia [14]. Another systematic review found no strong evidence for an association between circulating CRP and BC risk among prospective studies [12], while a third systematic review observed a modest but significant positive association [15]. Analyses of the Women's Health Study found that baseline CRP level was not associated with risk of invasive $\mathrm{BC}$ during 10 years of follow-up [16, 17], however, in the Women's Health Initiative, prediagnostic CRP was associated with an increased BC risk among lean women, whereas no association was observed among overweight-obese women [18]. On the contrary, another study in Europe found a positive association between CRP levels and postmenopausal
$\mathrm{BC}$ risk restricted to women with excess adiposity [19]. Further research on this topic is needed to clarify this relationship. Additionally, it is worth noting that most of these past studies have been conducted in populations from the United States and Europe, among mostly White study populations, and to our knowledge, none have been conducted in populations from Africa.

Notably, few epidemiological studies have analyzed the relationship between CRP levels and $\mathrm{BC}$ by molecular subtype, and results have been conflicting. One study in Italy reported a significant association between high CRP and TNBC and luminal B premenopausal BC [20], while another study in China found an association only for hormone receptor positive and HER2 negative BC [21]. Ours is the first study, to our knowledge, to evaluate this relationship on the African continent, where TNBC prevalence is notably higher. Because CRP is an easily measurable biomarker, further insight on this association may elucidate its potential as a simple and cost-effective method for predicting future risk of $\mathrm{BC}$, and as an additional prognostic predictor for survival among $\mathrm{BC}$ patients.

\section{RESULTS}

Of the 555 women included in the study cohort, 296 (53\%) were confirmed BC cases, and 259 (47\%) were controls (Figure 1). Compared to controls, cases had higher high-sensitivity CRP (hsCRP) (median 3.9 vs. $1.8 \mathrm{mg} / \mathrm{L}$, $p<0.001$ ) (Table 1; Figures 2 and 3). Cases were also more likely to report prior diagnosis of diabetes $(26.0 \%$ vs. $15.1 \%, p<0.001)$, hypertension $(18.9 \%$ vs. $48.3 \%$, $p<0.001)$ and past use of hormone replacement therapy compared with controls $(0.7 \%$ vs. $15.1 \% ; p<0.001)$. No statistically significant differences were found between cases and controls on age at enrollment, age at menarche, number of pregnancies and number of live births (all $p$-value $\geq 0.05$ ). Across hsCRP categories, no statistically significant differences were found between cases and controls in age at enrollment, body mass index (BMI), menopausal status, number of pregnancies and number of live births (all $p$-value $\geq 0.05$ ) (Supplementary Table 1).

High hsCRP $(>3.0 \mathrm{mg} / \mathrm{L})$ was associated with increased odds of $\mathrm{BC}$ in unadjusted models (OR: 3.61; 95\% CI: 2.34, 5.55), age-adjusted models (aOR: 3.60; $95 \%$ CI: $2.34,5.54$ ) and in models adjusting for age and reproductive variables (aOR: 4.46; 95\% CI: 2.70, 7.38) (Table 2). After additionally adjusting for BMI, diabetes, and hypertension, there was an almost 5 -fold increased odds of BC (aOR: 4.43, 95\% CI: 2.56, 7.66). Doubling of hsCRP concentration was associated with about $30 \%$ increased odds of BC (aOR: 1.31, 95\% CI: 1.19, 1.45) in models adjusting for age, BMI, diabetes, hypertension, and reproductive variables. Regardless of menopausal status, high hsCRP remained associated with increased odds of $\mathrm{BC}$ in all models considered. In BMI stratified 
Table 1: Clinical and reproductive characteristics among breast cancer cases and controls

\begin{tabular}{|c|c|c|c|c|}
\hline & Case $(N=296)$ & Control $(N=259)$ & Total $(N=555)$ & $p$ value \\
\hline \multicolumn{5}{|l|}{ Demographics } \\
\hline Age (years) ${ }^{\mathrm{a}}$ & $48(23-85)$ & $49(18-74)$ & $49(18-85)$ & $0.632^{1}$ \\
\hline \multicolumn{5}{|l|}{ Clinical characteristics } \\
\hline hsCRP $(\mathrm{mg} / \mathrm{L})^{\mathrm{a}}$ & $3.9(0.1-252.0)$ & $1.8(0.1-129.9)$ & $2.4(0.1-252.0)$ & $<0.001^{1}$ \\
\hline hsCRP (mg/L), categorical & & & & $<0.001^{2}$ \\
\hline$<1.0$ & $53(17.9 \%)$ & $91(35.1 \%)$ & $144(25.9 \%)$ & \\
\hline $1.0-3.0$ & $75(25.3 \%)$ & $88(34.0 \%)$ & $163(29.4 \%)$ & \\
\hline$>3.0$ & $168(56.8 \%)$ & $80(30.9 \%)$ & $248(44.7 \%)$ & \\
\hline $\operatorname{BMI}\left(\mathrm{kg} / \mathrm{m}^{2}\right)$ & & & & $0.086^{2}$ \\
\hline Underweight & $16(5.4 \%)$ & $6(2.3 \%)$ & $22(3.9 \%)$ & \\
\hline Normal weight & $120(40.5 \%)$ & $93(35.9 \%)$ & $213(38.4 \%)$ & \\
\hline Overweight & $88(29.7 \%)$ & $79(30.5 \%)$ & $167(30.1 \%)$ & \\
\hline Obese & $65(22.0 \%)$ & $81(31.3 \%)$ & $146(26.3 \%)$ & \\
\hline Height, $\mathrm{cm}^{\mathrm{a}}$ & $63.1(56.1-70.1)$ & $63.0(51.8-69.5)$ & $63.0(51.8-70.1)$ & $0.205^{1}$ \\
\hline Weight, $\mathrm{kg}^{\mathrm{a}}$ & $143.0(81.6-255.2)$ & 149.5 (78.9-289.7) & $145.2(78.9-289.7)$ & $0.019^{1}$ \\
\hline Systolic BPa & $125.0(84.0-236.0)$ & $127.7(77.7-231.3)$ & $126.7(77.7-236.0)$ & $0.407^{1}$ \\
\hline Diastolic $\mathrm{BP}^{\mathrm{a}}$ & $79.7(41.0-136.0)$ & $76.7(35.3-128.7)$ & $78.0(35.3-136.0)$ & $0.215^{1}$ \\
\hline Prior diabetes diagnosis & $77(26.0 \%)$ & $39(15.1 \%)$ & $116(20.9 \%)$ & $<0.001^{2}$ \\
\hline Prior hypertension diagnosis & $56(18.9 \%)$ & $125(48.3 \%)$ & $181(32.6 \%)$ & $<0.001^{2}$ \\
\hline \multicolumn{5}{|l|}{ Reproductive history } \\
\hline Age at menarche ${ }^{a}$ & $15(9-22)$ & $15(10-28)$ & $15(9-28)$ & $0.507^{1}$ \\
\hline Ever pregnant & $282(95.3 \%)$ & $243(93.8 \%)$ & $525(94.6 \%)$ & $0.500^{2}$ \\
\hline Number of pregnancies ${ }^{\mathrm{a}, \mathrm{b}}$ & $5(1-11)$ & $5(1-14)$ & $5(1-14)$ & $0.965^{1}$ \\
\hline Number of births ${ }^{\mathrm{a}, \mathrm{b}}$ & $4(0-10)$ & $4(0-16)$ & $4(0-16)$ & $0.523^{1}$ \\
\hline Menopausal status & & & & $0.504^{2}$ \\
\hline Pre- or peri-menopause & $143(48.3 \%)$ & $109(42.1 \%)$ & $252(45.4 \%)$ & \\
\hline Post-menopause & $153(51.7 \%)$ & $131(50.6 \%)$ & $284(51.2 \%)$ & \\
\hline Ever used HRT & $2(0.7 \%)$ & $39(15.1 \%)$ & $41(7.4 \%)$ & $<0.001^{2}$ \\
\hline
\end{tabular}

${ }^{1}$ Wilcoxon rank sum test, ${ }^{2} \mathrm{Chi}-$ Square test. ${ }^{\mathrm{a}}$ Median (range); ${ }^{\mathrm{b}}$ Among those who were ever pregnant. Where applicable, missing values were not used in generating $p$-value.

analyses, high hsCRP was associated with increased odds of $\mathrm{BC}$ regardless of BMI status (Table 3 ).

In multinomial logistic regression models evaluating the odds of $\mathrm{BC}$ molecular subtypes compared with controls (Table 4), high hsCRP (>3.0 mg/L) was statistically significantly associated with increased odds of luminal A (aOR: 4.03; 95\% CI: 1.29, 12.64), TN (aOR: 3.32; 95\% CI: 1.07, 10.35), and HER2-enriched (aOR: 6.27; 95\% CI: 1.69, 23.25) BC subtypes. Doubling of hsCRP concentration was associated with 23\%, 19\%, 30\% and $39 \%$ increased odds of luminal A, luminal B, TN, and HER2-enriched BC subtypes, respectively, although the association was not statistically significant for the luminal B subtype. In sensitivity analyses excluding women with hsCRP values $>10 \mathrm{mg} / \mathrm{L}$, patterns of association were largely consistent with overall analyses (data not shown).

\section{DISCUSSION}

In the first analysis of hsCRP among newly diagnosed $\mathrm{BC}$ cases and healthy controls in Nigeria, we observed that cases were significantly more likely to have high hsCRP compared with controls. After adjusting for socio-demographic, clinical, and reproductive variables, high hsCRP was associated with a statistically significant 4-fold increased odds of $\mathrm{BC}$, an association that remained significant regardless of menopausal status and BMI category. We also provide novel evidence of associations between hsCRP and BC molecular subtypes, with significant associations observed for luminal A, TN, and HER-enriched subtypes.

These findings are consistent with several studies utilizing case-control and prospective cohort study 
Table 2: Multivariable associations of hsCRP and breast cancer by menopausal status

\begin{tabular}{|c|c|c|c|c|c|}
\hline & $\mathbf{n} / \mathbf{N}$ & $\begin{array}{c}\text { Model 1a }^{\mathrm{a}} \\
\text { OR (95\% CI) } \\
\end{array}$ & $\begin{array}{c}\text { Model 2b }^{\mathrm{b}} \\
\text { aOR }(95 \% \text { CI) }\end{array}$ & $\begin{array}{c}\text { Model 3c }^{\mathrm{c}} \\
\text { aOR }(95 \% \text { CI) }\end{array}$ & $\begin{array}{c}\text { Model 4 }^{\mathrm{d}} \\
\text { aOR }(95 \% \mathrm{CI})\end{array}$ \\
\hline \multicolumn{6}{|c|}{ All women } \\
\hline \multicolumn{6}{|c|}{ hsCRP $(\mathrm{mg} / \mathrm{L})$, AHA recommended categories } \\
\hline Tertile $1(0.1-1.0)$ & $53 / 144$ & Ref. & Ref. & Ref. & Ref. \\
\hline Tertile $2(1.0-3.0)$ & $75 / 163$ & $1.46(0.93-2.31)$ & $1.45(0.92-2.30)$ & $1.50(0.89-2.52)$ & $1.61(0.91-2.84)$ \\
\hline Tertile $3(>3.0)$ & $168 / 248$ & $3.61(2.34-5.55)$ & $3.60(2.34-5.54)$ & $4.46(2.70-7.38)$ & $4.43(2.56-7.66)$ \\
\hline${ }^{*}$ Continuous hsCRP $(\mathbf{m g} / \mathbf{L})$ & $296 / 555$ & $1.30(1.20-1.40)$ & $1.30(1.20-1.40)$ & $1.31(1.20-1.43)$ & $1.31(1.19-1.45)$ \\
\hline \multicolumn{6}{|c|}{ Pre-/Peri-Menopause } \\
\hline \multicolumn{6}{|c|}{ hsCRP (mg/L), AHA recommended categories } \\
\hline Tertile $1(0.1-1.0)$ & $30 / 70$ & Ref. & Ref. & Ref. & Ref. \\
\hline Tertile $2(1.0-3.0)$ & $32 / 67$ & $1.22(0.62-2.39)$ & $1.27(0.65-2.51)$ & $1.13(0.52-2.47)$ & $1.19(0.50-2.66)$ \\
\hline Tertile $3(>3.0)$ & $81 / 115$ & $3.18(1.71-5.91)$ & $3.26(1.74-6.10)$ & $4.64(2.22-9.72)$ & $4.69(2.10-10.51)$ \\
\hline${ }^{*}$ Continuous hsCRP $(\mathbf{m g} / \mathbf{L})$ & $143 / 252$ & $1.26(1.13-1.40)$ & $1.26(1.13-1.40)$ & $1.32(1.16-1.49)$ & $1.34(1.16-1.56)$ \\
\hline \multicolumn{6}{|c|}{ Post-Menopause } \\
\hline \multicolumn{6}{|c|}{ hsCRP (mg/L), AHA recommended categories } \\
\hline Tertile $1(0.1-1.0)$ & $23 / 69$ & Ref. & Ref. & Ref. & Ref. \\
\hline Tertile $2(1.0-3.0)$ & $43 / 88$ & $1.91(1.00-3.67)$ & $1.88(0.98-3.61)$ & $1.95(0.94-4.05)$ & $2.07(0.95-4.53)$ \\
\hline Tertile $3(>3.0)$ & $87 / 127$ & $4.35(2.33-8.13)$ & $4.35(2.33-8.14)$ & $4.48(2.24-8.98)$ & $4.34(2.05-9.22)$ \\
\hline${ }^{*}$ Continuous hsCRP $(\mathbf{m g} / \mathbf{L})$ & $153 / 284$ & $1.33(1.18-1.50)$ & $1.33(1.18-1.50)$ & $1.31(1.15-1.49)$ & $1.29(1.12-1.48)$ \\
\hline
\end{tabular}

"Continuous values of hsCRP are $\log _{2}$-transformed. ${ }^{\mathrm{a}}$ Model 1, unadjusted; ${ }^{\mathrm{b}}$ Model 2, adjusted for age; ${ }^{\mathrm{c}}$ Model 3 , additionally adjusted for reproductive characteristics: age at menarche, number of pregnancies, number of births, and menopausal status (not included in the stratified models); ${ }^{\mathrm{d}}$ Model 4, additionally adjusted for BMI, diabetes and hypertension status; Bolded values indicate significance at $p<0.05$. Abbreviations: OR, odds ratio; $\mathrm{CI}$, confidence interval; aOR, adjusted odds ratio. $n=$ Number of breast cancer cases within each category. $N=$ Number of women in each category.

designs in the United States, Europe, and Asia, as well as systematic reviews that have reported an increased risk of BC with elevated levels of CRP [14, 15, 22-25]. However, other studies have reported conflicting results and have failed to find a significant positive association [12, 26, 27]. One of these reviews noted that although most prevalent case-control or cross-sectional studies found higher CRP concentrations in cancer patients compared to healthy controls, prospective cohort studies provided no strong evidence for an association [12]. In addition to study design differences, the conflicting results may also be due to characteristics of study populations. For instance, a prospective cohort study in Europe noted no association between CRP levels and $\mathrm{BC}$ risk among postmenopausal women overall but observed a statistically significant increase in BC risk among overweight and obese postmenopausal women [19]. This finding is inconsistent with our results of a positive association regardless of menopausal status or BMI category. Another prospective cohort study in China found that elevated levels of CRP at baseline were associated with an increased risk of $\mathrm{BC}$ overall and among younger women [28]. It is worth noting that the majority of past studies have been conducted in mostly White populations from the United States and
Europe, and a few studies in Asia. Of those studies in the United States, no study to our knowledge has been specifically conducted among African American women despite notably higher CRP levels in this population [29]; ours is the first to characterize this association on the African continent.

We observed significant positive associations between hsCRP levels and odds of luminal A, TN, and HER2-enriched BC. Past research by molecular subtype is extremely limited. One study in Italy reported a positive association between high CRP and TN and luminal B premenopausal BC [20], while another study in China found that only hormone receptor positive and HER2 negative BC had elevated serum CRP [21]. We urge further epidemiological studies on this topic among diverse populations to better characterize the association of CRP with $\mathrm{BC}$ risk by molecular subtype.

Several reasons may explain our observed positive association between hsCRP levels and odds of BC. It has been well documented that systemic and chronic inflammation is induced by obesity, alcohol consumption, and other poor lifestyle factors, leading to the development of cancer via the secretion of pro-inflammatory molecules and the dysregulation of physiological processes such as 
Table 3: Multivariable associations of hsCRP and breast cancer by BMI category

\begin{tabular}{|c|c|c|c|c|c|}
\hline & $\mathbf{n} / \mathbf{N}$ & $\begin{array}{c}\text { Model 1a }^{\mathrm{a}} \\
\text { OR (95\% CI) }\end{array}$ & $\begin{array}{c}\text { Model 2b }^{\mathrm{b}} \\
\text { aOR }(95 \% \text { CI) }\end{array}$ & $\begin{array}{c}\text { Model 3c } \\
\text { aOR }(95 \% \text { CI) }\end{array}$ & $\begin{array}{c}\text { Model 4 }^{\mathrm{d}} \\
\text { aOR }(95 \% \mathrm{CI})\end{array}$ \\
\hline \multicolumn{6}{|c|}{ Normal weight } \\
\hline \multicolumn{6}{|c|}{ hsCRP (mg/L), AHA recommended categories } \\
\hline Tertile $1(0.1-1.0)$ & $26 / 67$ & Ref. & Ref. & Ref. & Ref. \\
\hline Tertile $2(1.0-3.0)$ & $27 / 55$ & $1.52(0.74-3.13)$ & $1.44(0.69-3.00)$ & $1.44(0.59-3.50)$ & $1.51(0.59-3.88)$ \\
\hline Tertile $3(>3.0)$ & $67 / 91$ & $4.40(2.24-8.67)$ & $4.65(2.33-9.27)$ & $5.02(2.12-11.90)$ & $5.72(2.22-14.74)$ \\
\hline${ }^{*}$ Continuous hsCRP (mg/L) & $120 / 213$ & $1.31(1.17-1.47)$ & $1.32(1.00-1.05)$ & $1.30(1.12-1.50)$ & $1.31(1.12-1.54)$ \\
\hline \multicolumn{6}{|c|}{ Overweight } \\
\hline \multicolumn{6}{|c|}{ hsCRP (mg/L), AHA recommended categories } \\
\hline Tertile $1(0.1-1.0)$ & $15 / 42$ & Ref. & Ref. & Ref. & Ref. \\
\hline Tertile $2(1.0-3.0)$ & $26 / 52$ & $1.80(0.78-4.14)$ & $1.79(0.78-4.12)$ & $2.05(0.77-5.44)$ & $2.21(0.77-6.31)$ \\
\hline Tertile $3(>3.0)$ & $47 / 73$ & $3.25(1.47-7.19)$ & $3.34(1.50-7.41)$ & $4.96(1.91-12.89)$ & $4.11(1.47-11.51)$ \\
\hline${ }^{*}$ Continuous hsCRP (mg/L) & $88 / 167$ & $1.29(1.11-1.49)$ & $1.29(1.11-1.50)$ & $1.32(1.11-1.56)$ & $1.29(1.06-1.55)$ \\
\hline \multicolumn{6}{|c|}{ Obese } \\
\hline \multicolumn{6}{|c|}{ hsCRP (mg/L), AHA recommended categories } \\
\hline Tertile $1(0.1-1.0)$ & $7 / 29$ & Ref. & Ref. & Ref. & Ref. \\
\hline Tertile $2(1.0-3.0)$ & $16 / 48$ & $1.57(0.55-4.45)$ & $1.49(0.52-4.25)$ & $1.63(0.51-5.25)$ & $1.39(0.41-4.69)$ \\
\hline Tertile $3(>3.0)$ & $42 / 69$ & $4.89(1.84-13.00)$ & $4.89(1.83-13.03)$ & $6.32(2.09-19.08)$ & $5.35(1.72-16.62)$ \\
\hline${ }^{*}$ Continuous hsCRP (mg/L) & $65 / 146$ & $1.56(1.26-1.93)$ & $1.58(1.27-1.96)$ & $1.65(1.29-2.12)$ & $1.65(1.28-2.13)$ \\
\hline
\end{tabular}

${ }^{*}$ Continuous values of hsCRP are $\log _{2}$-transformed. ${ }^{a}$ Model 1, unadjusted; ${ }^{b}$ Model 2, adjusted for age; ${ }^{\mathrm{c} M o d e l} 3$, additionally adjusted for reproductive characteristics: age at menarche, number of pregnancies, number of births, and menopausal status (not included in the stratified models); ${ }^{\mathrm{d}}$ Model 4, additionally adjusted for BMI, diabetes and hypertension status; Bolded values indicate significance at $p<0.05$. Abbreviations: OR, odds ratio; $\mathrm{CI}$, confidence interval; aOR, adjusted odds ratio. $n=$ Number of breast cancer cases within each category. $N=$ Number of women in each category.

Table 4: Associations of hsCRP and breast cancer subtype

\begin{tabular}{|c|c|c|c|c|}
\hline & $\begin{array}{c}\text { Luminal A } \\
\operatorname{aOR}(95 \% \text { CI })\end{array}$ & $\begin{array}{c}\text { Luminal B } \\
\operatorname{aOR}(95 \% \mathrm{CI})\end{array}$ & $\begin{array}{l}\text { Triple Negative } \\
\text { aOR }(95 \% \mathrm{CI})\end{array}$ & $\begin{array}{c}\text { HER2 } \\
\text { aOR }(95 \% \text { CI })\end{array}$ \\
\hline \multicolumn{5}{|l|}{ hsCRP (mg/L) } \\
\hline Tertile $1(0.1-1.0)$ & Ref. & Ref. & Ref. & Ref. \\
\hline Tertile $2(1.0-3.0)$ & $1.14(0.30-4.29)$ & $0.99(0.32-3.07)$ & $2.52(0.80-7.97)$ & $1.67(0.37-7.21)$ \\
\hline Tertile $3(>3.0)$ & $4.03(1.02-12.64)$ & $1.80(0.61-5.29)$ & $3.32(1.07-10.35)$ & $6.27(1.69-23.25)$ \\
\hline${ }^{*}$ Continuous hsCRP $(\mathbf{m g} / \mathbf{L})$ & $1.23(1.02-1.49)$ & $1.19(0.99-1.43)$ & $1.30(1.09-1.55)$ & $1.39(1.15-1.69)$ \\
\hline
\end{tabular}

${ }^{*}$ Continuous values of hsCRP are $\log _{2}$-transformed. Multinomial logistic regression models predicted odds of specific breast cancer subtype versus controls. Adjusted for reproductive characteristics: age at menarche, number of pregnancies, number of births, and menopausal status, BMI, hypertension and diabetes status. Bolded values indicate significance at $p<0.05$. Abbreviations: aOR, adjusted odds ratio; $\mathrm{CI}$, confidence interval.

oxidative stress mechanisms and autophagy [30-32]. The inflammatory response can also induce genetic changes, such as mutations in tumor suppressor genes, leading to the development and progression of cancer [32]. For example, in the context of obesity, inflammatory mediators are released in response to the excessive accumulation of macronutrients in adipose tissue in order to maintain homeostasis [31], and regular use of nonsteroidal antiinflammatory drugs is associated with reduced $\mathrm{BC}$ risk
[33]. However, because we did not record the use of these drugs in our study, we were unable to examine this association in the present analysis. Underlying infections, highly prevalent in the Nigerian context, may also induce systemic inflammation, although there is no data suggesting an association between infections and $\mathrm{BC}$ among Nigerian women. However, chronic stress due to a recent diagnosis of $\mathrm{BC}$ may increase systemic inflammation, potentially explaining our findings. Future 
$\underline{\text { Breast Cancer Cases }}$

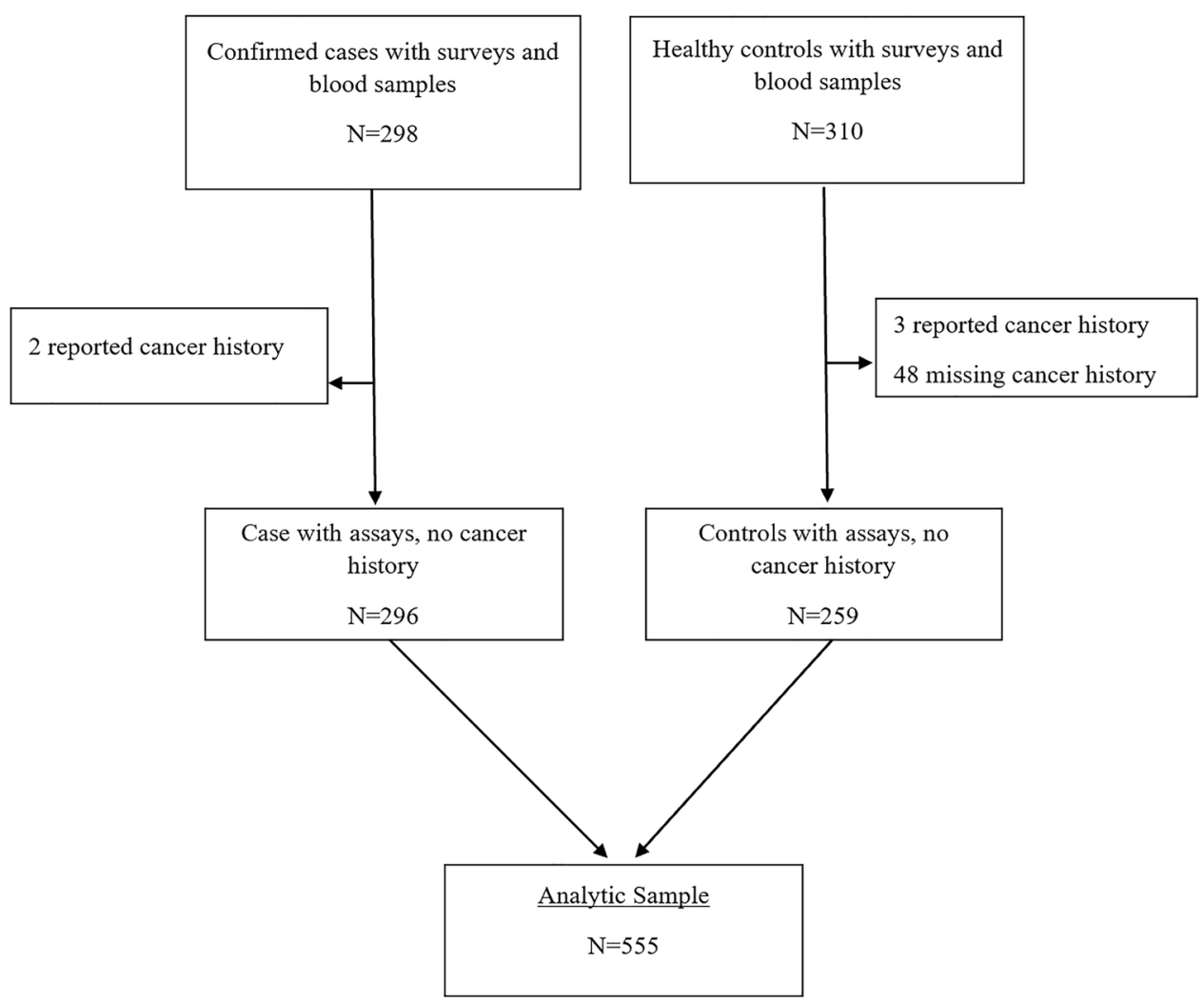

Figure 1: CONSORT diagram for MEND hsCRP analysis.

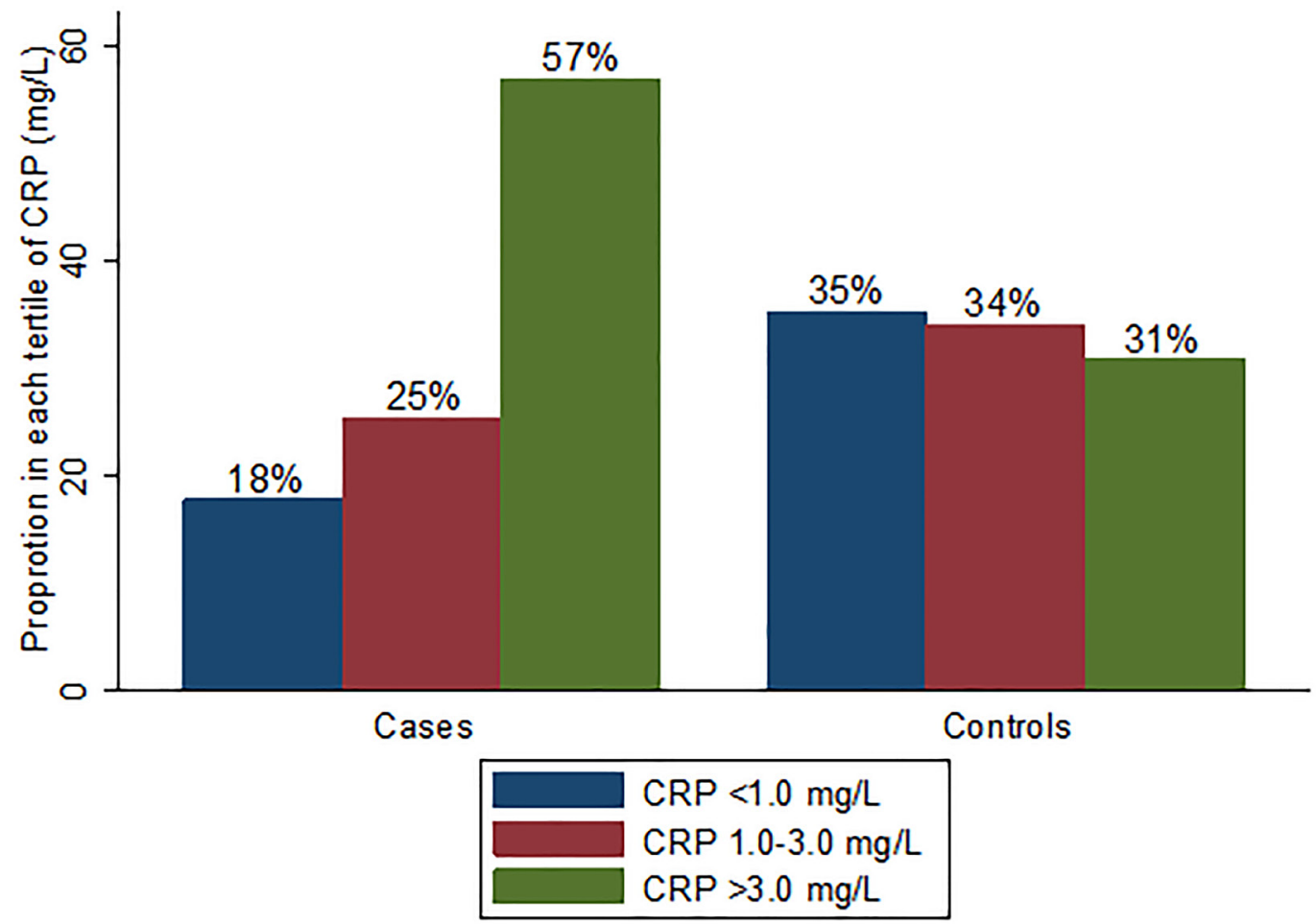

Figure 2: Proportion in each hsCRP category by case-control group. 
studies in this population may help to clarify the biological mechanisms linking CRP with BC by molecular subtype.

Stromal cells which pertain to the tumor microenvironment (TME) have been shown to influence breast tumor progression [34-37]. These stromal cells are known as cancer-associated fibroblasts (CAF) and are thought to originate from tissue fibroblasts and mesenchymal stem cells (MSC) [38]. Further, adiposeand bone-marrow derived MSCs have been characterized as pro-cancerous [39-43]. Thus, the cellular makeup of the TME and its composition of inflammatory molecules and mediators collectively create an ecosystem that favors tumor growth [38, 44-48]. Indeed, it appears that tumorstroma-inflammatory pathways may be responsible for the aggressive nature of TNBC [49], and thus may explain why we observed an association between hsCRP and odds of TNBC. Although we are unable to confirm the role of the TME in our data, future research regarding the TME in TNBC, especially among women of African descent, for whom TNBC is most prevalent [50], may help to unlock new targets for treatment and prevention of this most aggressive and recalcitrant molecular BC subtype.

There are several strengths and limitations of our study that are worth noting in the interpretation of results. First, several of the covariates included in this study were self-reported by participants, introducing potential recall bias in our analysis. However, our main exposure, hsCRP, was measured from blood samples simultaneously for cases and controls following the same protocol, minimizing misclassification. Second, it is

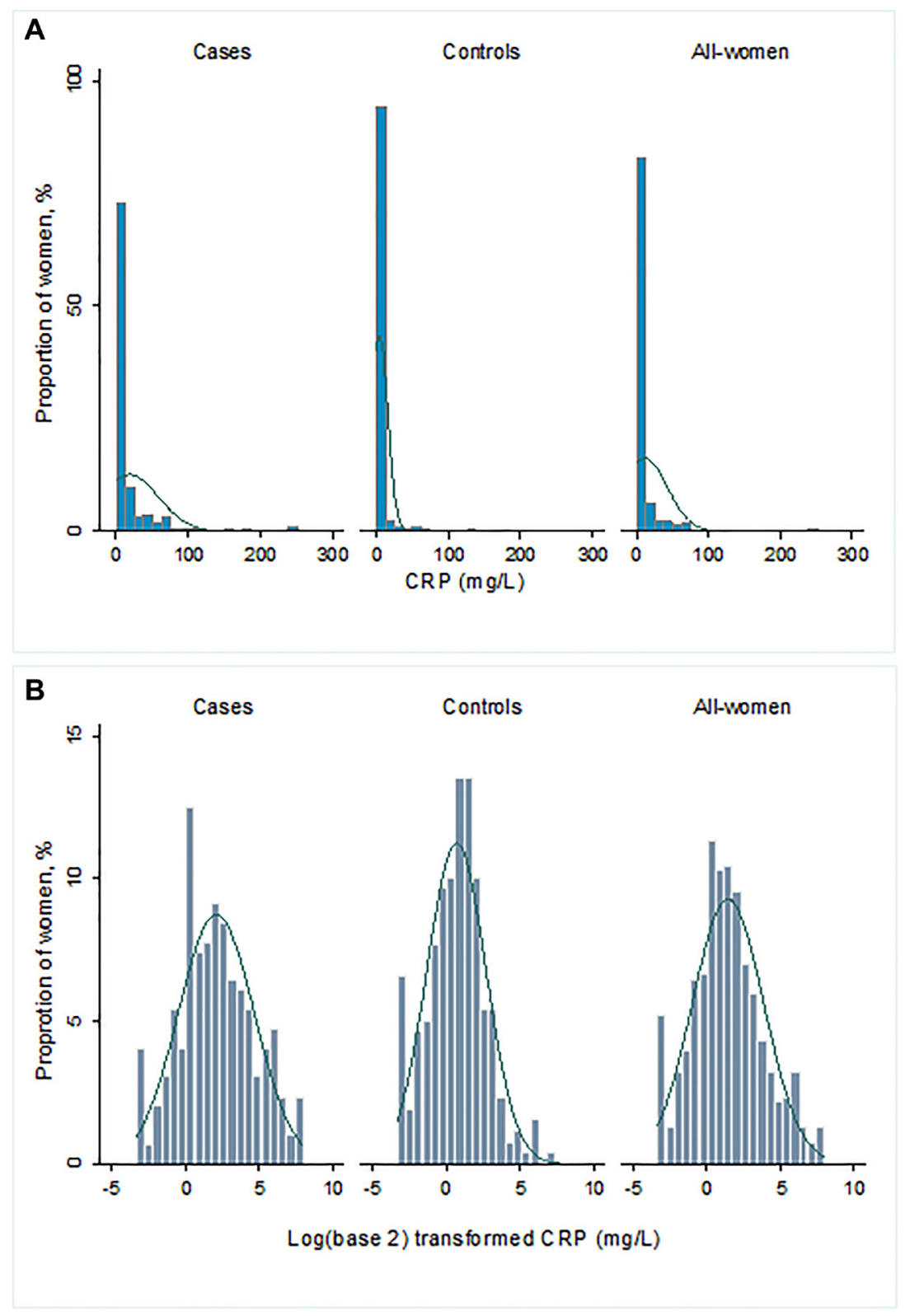

Figure 3: (A) Distribution of hsCRP (mg/L) and (B) $\log _{2}$-transformed hsCRP (mg/L). 
unclear whether CRP levels cause BC, or are influenced by the presence of BC. Our study design limits our ability to rule out potential reverse causality as blood hsCRP levels were measured from blood samples obtained at the time of BC diagnosis. Third, we did not examine CRP levels directly in the breast tissue. This was beyond the scope of the current analysis but is worth exploring in future studies. Fourth, we acknowledge our sample size limitation for the molecular subtype analysis but believe that our study lays an important foundation for future large prospective studies among women of African descent. Despite these limitations, important strengths of our study include the use of histologically confirmed $\mathrm{BC}$ cases with data on $\mathrm{BC}$ molecular subtype and adjustment for BMI and menopausal status among other key covariates. Additionally, ours is the first study to characterize the association between CRP levels and BC risk among Nigerian women, and further to do so by cancer molecular subtype.

In conclusion, our analysis revealed a positive association between hsCRP and odds of BC, overall and for all molecular subtypes. Because CRP is an easily measured biomarker in the blood, it may represent a useful predictor of $\mathrm{BC}$ in the Nigerian context. We urge larger studies, preferably prospective cohort studies, among women of African descent to further characterize this association.

\section{MATERIALS AND METHODS}

\section{Study design}

We have previously described The Mechanisms for Established and Novel Risk Factors for Breast Cancer in Women of African Descent (MEND) study in detail [51]. Briefly, newly diagnosed BC patients from four hospitals in southwestern Nigeria were enrolled in the MEND study between 2015 and 2019. A trained nurse explained the requirements of the study to $\mathrm{BC}$ patients during their clinical visits, and participants who expressed interest in participating were evaluated for eligibility. Patients were excluded if they were unable to communicate in English to complete the baseline survey or if they had other medical conditions that could affect participation. Upon providing verbal and written informed consent, study participants completed a questionnaire related to their sociodemographic characteristics, reproductive history, and past personal and family history of cancer. Next, anthropometric measurements were taken, and a blood sample and tumor biopsy sample were collected. All blood samples were obtained prior to surgery or chemotherapy treatment. Tissue and blood samples were processed and stored in $-80^{\circ} \mathrm{C}$ freezers until shipment to the United States for additional analysis. Participants received a N500 telephone recharge card (valued at US \$1.50) in addition to the supplies necessary for their biopsies for their participation in this study. Healthy controls with BC were selected from a cohort of 4,000 women recruited from Nigeria and Ghana as part of the Human Heredity and Health (H3) Africa Chronic Kidney Disease (CKD) Study [52]. H3Africa recruitment overlapped with case recruitment and occurred between 2015 and 2017. It involved the recruitment of healthy, community-based adult women, and the collection of extension sociodemographic, clinical, family history and behavioral risk factor data. Controls also provided blood samples. Sample and data collection protocols were similar between the CKD and MEND studies. Biospecimen for cases and controls were assayed at the same time in the same laboratory with the laboratory technician blinded to case status. These procedures were approved by the Institutional Review Boards at Duke University and the participating hospitals.

\section{Breast cancer cases and subtyping}

$\mathrm{BC}$ cases were determined in one of two ways, either from pathology reports of clinical biopsy samples evaluated by a trained pathologist from the diagnosing hospital in Nigeria, or from samples that were shipped to the United States and evaluated by a pathologist. The sample was considered a confirmed case if either report indicated a cancer diagnosis. These samples underwent immunohistochemistry as part of regular standard of care procedures in Nigeria or at the Duke University BioRepository and Precision Pathology Center. United States typing was used if results from both sources were available, as it constituted most of the available immunohistochemistry information. The Allred method was used to score estrogen receptor (ER) and progesterone receptor (PR) status $[53,54]$. Stain intensity was categorized as 0 (none), 1 (mild), 2 (moderate), or 3 (strong). The proportion of nuclear positivity was defined as $0(0 \%), 1(<1 \%), 2(1-10 \%), 3(11-33 \%), 4(33-66 \%)$ or $5(67-100 \%)$. ER/PR status was categorized as positive (3-8) or negative (0-2). HER2 status was defined as negative (scores $=0-1)$ or positive $($ score $=3$ ) [55]. There were no equivocal (score $=2$ ) results in our sample. From these categorizations of hormone receptor status, BC molecular subtype was determined: luminal A (ER+ and/or $\mathrm{PR}+$ / HER2-), luminal B (ER+ and/or PR+ / HER2+), TN (ER- / PR- / HER2-), or HER2 (ER- / PR- / HER2+). In total, 124 cases had data available on ER/PR/HER2 status and were classified into a molecular subtype.

\section{CRP and study covariates}

Biospecimens for confirmed BC cases with completed surveys were submitted to the Duke Molecular Physiology Institute Immunoassay laboratory for analysis and tested for hsCRP. These measurements were performed using a latex-enhanced immunoturbidimetric 
assay from Beckman (Brea, CA, USA) on a Beckman DxC 600 clinical analyzer. BMI $\left(\mathrm{kg} / \mathrm{m}^{2}\right)$ was calculated from height and weight which were collected by trained research staff at enrollment. Reproductive and clinical characteristics, including age at menarche, number of pregnancies and births, menopausal status, prior diabetes, and hypertension diagnosis were self-reported by participants. Participants who self-reported a history of cancer or missing personal cancer history were excluded from analysis. Missing data for all variables were not used for statistical analyses.

\section{Statistical analysis}

hsCRP was categorized into $<1.0 \mathrm{mg} / \mathrm{L}, 1.0-3.0 \mathrm{mg} / \mathrm{L}$ and $>3.0 \mathrm{mg} / \mathrm{L}$ according to the American Heart Association and U.S Centers for Disease Control and Prevention guidelines [56]. Differences in demographic, clinical and reproductive characteristics were compared between cases and controls as well as by hsCRP categories using Wilcoxon rank sum/Kruskal-Wallis tests for continuous variables and $\chi^{2}$ (chi-squared) tests for categorical variables. Univariable and multivariable logistic regression models were used to test the association between hsCRP (separately assessed as categorical and continuous ( $\log _{2}$-transformed)) and $\mathrm{BC}$ diagnosis. Estimates for the $\log _{2}$-transformed hsCRP are interpreted as the relative risk associated with a doubling in hsCRP concentration [57]. Multivariable models were adjusted for (a) age at enrollment only, (b) age at enrollment, age at menarche, number of pregnancies (categorized as $<$ 4 vs. $\geq 4$ ), number of births (categorized as $<4$ vs. $\geq 4$ ) and menopausal status and (c) in addition to variables in (b), BMI, hypertension, and diabetes. Hypertension status was self-reported among cases and controls. Among cases, women with fasting-glucose levels of $>100 \mathrm{mg} / \mathrm{dL}$ were classified as diabetic while among controls, diabetes status was self-reported. These models were repeated with stratification for menopausal status and BMI categories (Normal weight, Overweight and Obese). Furthermore, among BC cases with cancer subtyping data available, odds of luminal A, luminal B, TN, or HER2 cancer subtypes were compared to controls using multinomial logistic regression models. In sensitivity analyses, we repeated all analyses after excluding women with hsCRP values $>10$ $\mathrm{mg} / \mathrm{L}$. There was no statistically significant difference in hsCRP values between controls recruited in Nigeria and Ghana $(p=0.3363)$, therefore we present overall results. All statistical significance tests were two-sided with $p<0.05$ defined as significant. Statistical analyses were conducted using SAS Version 9.4 (SAS institute, Cary, NC, USA).

\section{Ethics statement}

The study was conducted according to the guidelines of the Declaration of Helsinki and approved by the Institutional Review Board of Duke University (protocol code Pro00102004, approved 5/17/2019). Informed consent was obtained from all subjects involved in the study.

\section{Abbreviations}

95\% CI: 95\% confidence interval; aOR: adjusted odds ratio; BMI: body mass index; $\mathrm{BC}$ : breast cancer; CAF: cancer-associated fibroblast; CKD: chronic kidney disease; CRP: C-reactive protein; ER: estrogen receptor; HER2: human epidermal growth factor-2; H3A: Human Heredity and Health Africa; hsCRP: high-sensitivity C-reactive protein; MEND: Mechanisms for Established and Novel Risk Factors for Breast Cancer in Women of African Descent; MSC: mesenchymal stem cell; OR: odds ratio; PR: progesterone receptor; TME: tumor microenvironment; TN: triple-negative.

\section{Author contributions}

Conceptualization, T.A.; methodology, T.A.; formal analysis, T.O., A.G., T.A.; resources, T.A., H3.A.K.R.N.; writing - original draft preparation, A.G.; writing - review and editing, A.G., T.O., O.S., A.D., O.A., G.O., A.A., A.D., V.S., A.H., O.A., T.O., O.O., O.A., A.A., O.A., A.O., A.A., T.O.T., D.A., M.J.M., C.B.N., T.A.; funding acquisition, T.A. All authors have read and agreed to the final version of the manuscript.

\section{ACKNOWLEDGMENTS}

We acknowledge the role of the H3Africa Consortium in making this research possible through the sharing of data. The National Institutes of Health (USA) and Wellcome Trust (UK) provided core funding for the H3Africa Consortium. We thank the many MEND investigators who contributed substantially to the inception and design of the study, and the patients and families who participated in the MEND study for their vital contribution in advancing the science of cancer in Nigeria and globally. We acknowledge the important contribution of the MEND research nurses: Cordelia Ibeneme, Peju Olabanji, Rebecca Israel, Esther Akinwale, Deborah Awodeyi, and Shukurat Oduola.

\section{Availability of data and materials}

The data that support the findings of the study are available from the corresponding author upon reasonable request.

\section{CONFLICTS OF INTEREST}

The authors declare no conflicts of interest. The funders had no role in the design of the study; in the collection, analyses, or interpretation of data; in the 
writing of the manuscript, or in the decision to publish the results.

\section{FUNDING}

This research was funded by National Institutes of Health, National Cancer Institute, Fogarty International Center, grant number K01TW010271 (T.A.) and National Institutes of Health, grant number NIH 1P30DK124723-01.

\section{Editorial note}

This paper has been accepted based in part on peerreview conducted by another journal and the authors' response and revisions as well as expedited peer-review in Oncotarget.

\section{REFERENCES}

1. Bray F, Ferlay J, Soerjomataram I, Siegel RL, Torre LA, Jemal A. Global cancer statistics 2018: GLOBOCAN estimates of incidence and mortality worldwide for 36 cancers in 185 countries. CA Cancer J Clin. 2018; 68:394 424. https://doi.org/10.3322/caac.21492. [PubMed]

2. Adeloye D, Sowunmi OY, Jacobs W, David RA, Adeosun AA, Amuta AO, Misra S, Gadanya M, Auta A, Harhay MO, Chan KY. Estimating the incidence of breast cancer in Africa: a systematic review and meta-analysis. J Glob Health. 2018; 8:010419. https://doi.org/10.7189/ jogh.08.010419. [PubMed]

3. Azubuike SO, Muirhead C, Hayes L, McNally R. Rising global burden of breast cancer: the case of sub-Saharan Africa (with emphasis on Nigeria) and implications for regional development: a review. World J Surg Oncol. 2018; 16:63. https://doi.org/10.1186/s12957-018-1345-2. [PubMed]

4. Wright N, Rida P, Rakha E, Agboola A, Aneja R. Panoptic Overview of Triple-Negative Breast Cancer in Nigeria: Current Challenges and Promising Global Initiatives. J Glob Oncol. 2018; 4:1-20. https://doi.org/10.1200/ JGO.17.00116. [PubMed]

5. Newman LA, Jenkins B, Chen Y, Oppong JK, Adjei E, Jibril AS, Hoda S, Cheng E, Chitale D, Bensenhaver JM, Awuah B, Bekele M, Abebe E, et al. Hereditary Susceptibility for Triple Negative Breast Cancer Associated With Western Sub-Saharan African Ancestry: Results From an International Surgical Breast Cancer Collaborative. Ann Surg. 2019; 270:484-92. https://doi.org/10.1097/ SLA.0000000000003459. [PubMed]

6. Dietze EC, Sistrunk C, Miranda-Carboni G, O'Regan R, Seewaldt VL. Triple-negative breast cancer in AfricanAmerican women: disparities versus biology. Nat Rev Cancer. 2015; 15:248-54. https://doi.org/10.1038/nrc3896. [PubMed]
7. Kumar P, Aggarwal R. An overview of triple-negative breast cancer. Arch Gynecol Obstet. 2016; 293:247-69. https://doi. org/10.1007/s00404-015-3859-y. [PubMed]

8. Newman LA. Breast cancer disparities: high-risk breast cancer and African ancestry. Surg Oncol Clin N Am. 2014; 23:579-92. https://doi.org/10.1016/j.soc.2014.03.014. [PubMed]

9. Yeyeodu ST, Kidd LR, Kimbro KS. Protective Innate Immune Variants in Racial/Ethnic Disparities of Breast and Prostate Cancer. Cancer Immunol Res. 2019; 7:1384-89. https://doi.org/10.1158/2326-6066.CIR-18-0564. [PubMed]

10. Sproston NR, Ashworth JJ. Role of C-Reactive Protein at Sites of Inflammation and Infection. Front Immunol. 2018; 9:754. https://doi.org/10.3389/fimmu.2018.00754. [PubMed]

11. Nehring SM, Goyal A, Bansal P, Patel BC. C Reactive Protein. StatPearls. Treasure Island (FL): StatPearls Publishing. 2021 Jan., Available from https://www.ncbi. nlm.nih.gov/books/NBK441843/. [PubMed]

12. Heikkilä K, Ebrahim S, Lawlor DA. A systematic review of the association between circulating concentrations of $\mathrm{C}$ reactive protein and cancer. J Epidemiol Community Health. 2007; 61:824-33. https://doi.org/10.1136/jech.2006.051292. [PubMed]

13. Roxburgh CS, McMillan DC. Role of systemic inflammatory response in predicting survival in patients with primary operable cancer. Future Oncol. 2010; 6:149 63. https://doi.org/10.2217/fon.09.136. [PubMed]

14. Guo L, Liu S, Zhang S, Chen Q, Zhang M, Quan P, Lu J, Sun X. C-reactive protein and risk of breast cancer: A systematic review and meta-analysis. Sci Rep. 2015; 5:10508. https://doi.org/10.1038/srep10508. [PubMed]

15. Chan DS, Bandera EV, Greenwood DC, Norat T. Circulating C-Reactive Protein and Breast Cancer Risk-Systematic Literature Review and Meta-analysis of Prospective Cohort Studies. Cancer Epidemiol Biomarkers Prev. 2015; 24:1439-49. https://doi.org/10.1158/1055-9965.EPI-150324. [PubMed]

16. Zhang SM, Lin J, Cook NR, Lee IM, Manson JE, Buring JE, Ridker PM. C-reactive protein and risk of breast cancer. J Natl Cancer Inst. 2007; 99:890-94. https://doi.org/10.1093/ jnci/djk202. [PubMed]

17. Tobias DK, Akinkuolie AO, Chandler PD, Lawler PR, Manson JE, Buring JE, Ridker PM, Wang L, Lee IM, Mora S. Markers of Inflammation and Incident Breast Cancer Risk in the Women's Health Study. Am J Epidemiol. 2018; 187:705-16. https://doi.org/10.1093/aje/kwx250. [PubMed]

18. Nelson SH, Brasky TM, Patterson RE, Laughlin GA, KritzSilverstein D, Edwards BJ, Lane D, Rohan TE, Ho GYF, Manson JE, LaCroix AZ. The Association of the C-Reactive Protein Inflammatory Biomarker with Breast Cancer Incidence and Mortality in the Women's Health Initiative. Cancer Epidemiol Biomarkers Prev. 2017; 26:1100-06. https://doi.org/10.1158/1055-9965.EPI-16-1005. [PubMed] 
19. Dossus L, Jimenez-Corona A, Romieu I, Boutron-Ruault MC, Boutten A, Dupré T, Fagherazzi G, Clavel-Chapelon F, Mesrine S. C-reactive protein and postmenopausal breast cancer risk: results from the E3N cohort study. Cancer Causes Control. 2014; 25:533-39. https://doi.org/10.1007/ s10552-014-0355-9. [PubMed]

20. Agresti R, Meneghini E, Baili P, Minicozzi P, Turco A, Cavallo I, Funaro F, Amash H, Berrino F, Tagliabue E, Sant M. Association of adiposity, dysmetabolisms, and inflammation with aggressive breast cancer subtypes: a cross-sectional study. Breast Cancer Res Treat. 2016; 157:179-89. https://doi.org/10.1007/s10549-016-3802-3. [PubMed]

21. Hong T, Liu A, Cai D, Zhang Y, Hua D, Hang X, Wu X. Preoperative serum C-reactive protein levels and early breast cancer by BMI and menopausal status. Cancer Invest. 2013; 31:279-85. https://doi.org/10.3109/07357907.2013.7 89898. [PubMed]

22. Il'yasova D, Colbert LH, Harris TB, Newman AB, Bauer DC, Satterfield S, Kritchevsky SB. Circulating levels of inflammatory markers and cancer risk in the health aging and body composition cohort. Cancer Epidemiol Biomarkers Prev. 2005; 14:2413-18. https://doi. org/10.1158/1055-9965.EPI-05-0316. [PubMed]

23. Ollberding NJ, Kim Y, Shvetsov YB, Wilkens LR, Franke AA, Cooney RV, Maskarinec G, Hernandez BY, Henderson BE, Le Marchand L, Kolonel LN, Goodman MT. Prediagnostic leptin, adiponectin, C-reactive protein, and the risk of postmenopausal breast cancer. Cancer Prev Res (Phila). 2013; 6:188-95. https://doi.org/10.1158/1940-6207. CAPR-12-0374. [PubMed]

24. Prizment AE, Folsom AR, Dreyfus J, Anderson KE, Visvanathan K, Joshu CE, Platz EA, Pankow JS. Plasma $\mathrm{C}$-reactive protein, genetic risk score, and risk of common cancers in the Atherosclerosis Risk in Communities study. Cancer Causes Control. 2013; 24:2077-87. https://doi. org/10.1007/s10552-013-0285-y. [PubMed]

25. Kaur RP, Rubal, Banipal RPS, Vashistha R, Dhiman M, Munshi A. Association of elevated levels of C-reactive protein with breast cancer, breast cancer subtypes, and poor outcome. Curr Probl Cancer. 2019; 43:123-29. https://doi. org/10.1016/i.currproblcancer.2018.05.003. [PubMed]

26. Allin KH, Nordestgaard BG. Elevated C-reactive protein in the diagnosis, prognosis, and cause of cancer. Crit Rev Clin Lab Sci. 2011; 48:155-70. https://doi.org/10.3109/1040836 3.2011.599831. [PubMed]

27. Gaudet MM, Patel AV, Teras LR, Sun J, Campbell PT, Stevens VL, Jacobs EJ, Gapstur SM. Obesity-related markers and breast cancer in CPS-II Nutrition Cohort. Int J Mol Epidemiol Genet. 2013; 4:156-66. [PubMed]

28. Wang G, Li N, Chang S, Bassig BA, Guo L, Ren J, Su K, Li F, Chen S, Wu S, Zou Y, Dai M, Zheng T, He J. A prospective follow-up study of the relationship between C-reactive protein and human cancer risk in the Chinese Kailuan Female Cohort. Cancer Epidemiol Biomarkers
Prev. 2015; 24:459-65. https://doi.org/10.1158/1055-9965. EPI-14-1112. [PubMed]

29. Khera A, McGuire DK, Murphy SA, Stanek HG, Das SR, Vongpatanasin W, Wians FH Jr, Grundy SM, de Lemos JA. Race and gender differences in C-reactive protein levels. J Am Coll Cardiol. 2005; 46:464-69. https://doi. org/10.1016/j.jacc.2005.04.051. [PubMed]

30. Suman S, Sharma PK, Rai G, Mishra S, Arora D, Gupta P, Shukla Y. Current perspectives of molecular pathways involved in chronic inflammation-mediated breast cancer. Biochem Biophys Res Commun. 2016; 472:401-09. https:// doi.org/10.1016/i.bbrc.2015.10.133. [PubMed]

31. Deshmukh SK, Srivastava SK, Poosarla T, Dyess DL, Holliday NP, Singh AP, Singh S. Inflammation, immunosuppressive microenvironment and breast cancer: opportunities for cancer prevention and therapy. Ann Trans1 Med. 2019; 7:593. https://doi.org/10.21037/atm.2019.09.68. [PubMed]

32. Hussain SP, Harris CC. Inflammation and cancer: an ancient link with novel potentials. Int J Cancer. 2007; 121:2373-80. https://doi.org/10.1002/ijc.23173. [PubMed]

33. Luo T, Yan HM, He P, Luo Y, Yang YF, Zheng H. Aspirin use and breast cancer risk: a meta-analysis. Breast Cancer Res Treat. 2012; 131:581-87. https://doi.org/10.1007/ s10549-011-1747-0. [PubMed]

34. Al-Rakan MA, Colak D, Hendrayani SF, Al-Bakheet A, AlMohanna FH, Kaya N, Al-Malik O, Aboussekhra A. Breast stromal fibroblasts from histologically normal surgical margins are pro-carcinogenic. J Pathol. 2013; 231:457-65. https://doi.org/10.1002/path.4256. [PubMed]

35. Hembruff SL, Jokar I, Yang L, Cheng N. Loss of transforming growth factor-beta signaling in mammary fibroblasts enhances CCL2 secretion to promote mammary tumor progression through macrophage-dependent and -independent mechanisms. Neoplasia. 2010; 12:425-33. https://doi.org/10.1593/neo.10200. [PubMed]

36. Trimboli AJ, Cantemir-Stone CZ, Li F, Wallace JA, Merchant A, Creasap N, Thompson JC, Caserta E, Wang H, Chong JL, Naidu S, Wei G, Sharma SM, et al. Pten in stromal fibroblasts suppresses mammary epithelial tumours. Nature. 2009; 461:1084-91. https://doi.org/10.1038/ nature08486. [PubMed]

37. Yashiro M, Ikeda K, Tendo M, Ishikawa T, Hirakawa K. Effect of organ-specific fibroblasts on proliferation and differentiation of breast cancer cells. Breast Cancer Res Treat. 2005; 90:307-13. https://doi.org/10.1007/s10549004-5364-z. [PubMed]

38. Katanov C, Lerrer S, Liubomirski Y, Leider-Trejo L, Meshel T, Bar J, Feniger-Barish R, Kamer I, Soria-Artzi G, Kahani H, Banerjee D, Ben-Baruch A. Regulation of the inflammatory profile of stromal cells in human breast cancer: prominent roles for TNF- $\alpha$ and the NF- $\kappa \mathrm{B}$ pathway. Stem Cell Res Ther. 2015; 6:87. https://doi.org/10.1186/ s13287-015-0080-7. [PubMed] 
39. Bergfeld SA, DeClerck YA. Bone marrow-derived mesenchymal stem cells and the tumor microenvironment. Cancer Metastasis Rev. 2010; 29:249-61. https://doi. org/10.1007/s10555-010-9222-7. [PubMed]

40. Lin SY, Dolfi SC, Amiri S, Li J, Budak-Alpdogan T, Lee KC, Derenzo C, Banerjee D, Glod J. P53 regulates the migration of mesenchymal stromal cells in response to the tumor microenvironment through both CXCL12-dependent and -independent mechanisms. Int J Oncol. 2013; 43:181723. https://doi.org/10.3892/ijo.2013.2109. [PubMed]

41. Quante M, Tu SP, Tomita H, Gonda T, Wang SS, Takashi S, Baik GH, Shibata W, Diprete B, Betz KS, Friedman R, Varro A, Tycko B, Wang TC. Bone marrow-derived myofibroblasts contribute to the mesenchymal stem cell niche and promote tumor growth. Cancer Cell. 2011; 19:257-72. https://doi. org/10.1016/j.ccr.2011.01.020. [PubMed]

42. Spaeth EL, Dembinski JL, Sasser AK, Watson K, Klopp A, Hall B, Andreeff M, Marini F. Mesenchymal stem cell transition to tumor-associated fibroblasts contributes to fibrovascular network expansion and tumor progression. PLoS One. 2009; 4:e4992. https://doi.org/10.1371/journal. pone.0004992. [PubMed]

43. Uchibori R, Tsukahara T, Mizuguchi H, Saga Y, Urabe M, Mizukami H, Kume A, Ozawa K. NF- $\kappa$ B activity regulates mesenchymal stem cell accumulation at tumor sites. Cancer Res. 2013; 73:364-72. https://doi.org/10.1158/0008-5472. CAN-12-0088. [PubMed]

44. Allen MD, Jones LJ. The role of inflammation in progression of breast cancer: Friend or foe? (Review). Int J Oncol. 2015; 47:797-805. https://doi.org/10.3892/ ijo.2015.3075. [PubMed]

45. Allen M, Louise Jones J. Jekyll and Hyde: the role of the microenvironment on the progression of cancer. J Pathol. 2011; 223:162-76. https://doi.org/10.1002/path.2803. [PubMed]

46. Colotta F, Allavena P, Sica A, Garlanda C, Mantovani A. Cancer-related inflammation, the seventh hallmark of cancer: links to genetic instability. Carcinogenesis. 2009; 30:1073-81. https://doi.org/10.1093/carcin/bgp127. [PubMed]

47. Qian BZ, Pollard JW. Macrophage diversity enhances tumor progression and metastasis. Cell. 2010; 141:39-51. https:// doi.org/10.1016/j.cell.2010.03.014. [PubMed]

48. Sica A, Porta C, Morlacchi S, Banfi S, Strauss L, Rimoldi M, Totaro MG, Riboldi E. Origin and Functions of TumorAssociated Myeloid Cells (TAMCs). Cancer Microenviron. 2012; 5:133-49. https://doi.org/10.1007/s12307-011-00916. [PubMed]

49. Liubomirski Y, Lerrer S, Meshel T, Morein D, RubinsteinAchiasaf L, Sprinzak D, Wiemann S, Körner C, Ehrlich M, Ben-Baruch A. Notch-Mediated Tumor-StromaInflammation Networks Promote Invasive Properties and CXCL8 Expression in Triple-Negative Breast Cancer. Front Immunol. 2019; 10:804. https://doi.org/10.3389/ fimmu.2019.00804. [PubMed]
50. Newman LA. Disparities in breast cancer and african ancestry: a global perspective. Breast J. 2015; 21:133-39. https://doi.org/10.1111/tbj.12369. [PubMed]

51. Akinyemiju T, Salako O, Daramola A, Alatise O, Adeniyi A, Ogun G, Ayandipo O, Olajide T, Olasehinde O, Arowolo O, Adisa A, Afuwape O, Olusanya A, et al. Collaborative Molecular Epidemiology Study of Metabolic Dysregulation, DNA Methylation, and Breast Cancer Risk Among Nigerian Women: MEND Study Objectives and Design. J Glob Oncol. 2019; 5:1-9. https://doi.org/10.1200/JGO.18.00226. [PubMed]

52. Osafo C, Raji YR, Burke D, Tayo BO, Tiffin N, MoxeyMims MM, Rasooly RS, Kimmel PL, Ojo A, Adu D, Parekh RS, and H3Africa Kidney Disease Research Network Investigators as members of The H3Africa Consortium. Human Heredity and Health (H3) in Africa Kidney Disease Research Network: A Focus on Methods in Sub-Saharan Africa. Clin J Am Soc Nephrol. 2015; 10:2279-87. https:// doi.org/10.2215/CJN.11951214. [PubMed]

53. Mukherjee T. Interpretation of ER and Her2neu hormonal receptor in breast cancer. Med J Armed Forces India. 2016; 72:99. https://doi.org/10.1016/j.mjafi.2015.11.007. [PubMed]

54. Hammond ME, Hayes DF, Dowsett M, Allred DC, Hagerty KL, Badve S, Fitzgibbons PL, Francis G, Goldstein NS, Hayes M, Hicks DG, Lester S, Love R, et al, and American Society of Clinical Oncology, and College of American Pathologists. American Society of Clinical Oncology/College of American Pathologists guideline recommendations for immunohistochemical testing of estrogen and progesterone receptors in breast cancer (unabridged version). Arch Pathol Lab Med. 2010; 134:e48-72. https://doi.org/10.5858/134.7.e48. [PubMed]

55. Wolff AC, Hammond ME, Schwartz JN, Hagerty KL, Allred DC, Cote RJ, Dowsett M, Fitzgibbons PL, Hanna WM, Langer A, McShane LM, Paik S, Pegram MD, et al, and American Society of Clinical Oncology/College of American Pathologists. American Society of Clinical Oncology/College of American Pathologists guideline recommendations for human epidermal growth factor receptor 2 testing in breast cancer. Arch Pathol Lab Med. 2007; 131:18-43. https://doi.org/10.5858/2007-131-18ASOCCO. [PubMed]

56. Pearson TA, Mensah GA, Alexander RW, Anderson JL, Cannon RO 3rd, Criqui M, Fadl YY, Fortmann SP, Hong Y, Myers GL, Rifai N, Smith SC Jr, Taubert K, et al, and Centers for Disease Control and Prevention, and American Heart Association. Markers of inflammation and cardiovascular disease: application to clinical and public health practice: A statement for healthcare professionals from the Centers for Disease Control and Prevention and the American Heart Association. Circulation. 2003; 107:499-511. https://doi. org/10.1161/01.cir.0000052939.59093.45. [PubMed]

57. Muller DC, Larose TL, Hodge A, Guida F, Langhammer A, Grankvist K, Meyer K, Cai Q, Arslan AA, Zeleniuch- 
Jacquotte A, Albanes D, Giles GG, Sesso HD, et al. Circulating high sensitivity $\mathrm{C}$ reactive protein concentrations and risk of lung cancer: nested case-control study within Lung Cancer Cohort Consortium. BMJ. 2019; 364:k4981. https://doi.org/10.1136/bmj.k4981. [PubMed] 